\title{
SEISMIC DESIGN OF MULTISTOREYED RC BUILDING USING VARIOUS CODES
}

\author{
Pamela Jennifer $\mathbf{J} \mathbf{P}^{1}$, Jegidha. K. $\mathbf{J}^{\mathbf{2}}$, Sureshbabu. $\mathbf{S}^{\mathbf{3}}$ \\ ${ }^{I}$ PG Scholar, Department of Civil Engineering, Adhiyamaan College of Engineering, Hosur, Krishnagiri, India. \\ pamejenni12@gmail.com \\ ${ }^{2}$ Assistant Professor, Department of Civil Engineering, Adhiyamaan College of Engineering Hosur, Krishnagiri, \\ India. \\ jegi.kj@gmail.com \\ ${ }^{3}$ HOD, Department of Civil Engineering, Adhiyamaan College of Engineering Hosur, Krishnagiri, India
}

\begin{abstract}
Earthquake is a major phenomenon which cause failure to the Reinforced Concrete $(R C)$ structure. The necessity of designing the structure as per codal provision is must for all kind of structure. In this research, a building of regular plan of $G+10$ was taken for study. The Linear static analysis was done using American, European and Indian Codes. The building is modeled and analysed using ETABS software. All the required parameters for analysis was taken as per respective codes. Various response like storey deflection, storey drift and base shear were compared. The displacement, storey shear and storey displacement obtained from ACI code design is more when compared with other code's analysis result.
\end{abstract}

Keywords: Displacement, Shear, Drift, Seismic Analysis

\section{HEADING 1}

\section{INTRODUCTION}

Earthquake resistant structures are capable of resisting lateral and vertical forces acting on the structures. But no structures can entirely survive during earthquake without any damages. According to codes, earthquake resistant structures are designed to withstand expected earthquake atleast to occur once during the design life of the structure. Reinforced concrete buildings are analysed and designed to meet the requirements of relevant codes of practice. Such buildings designed as per codal provision will survive during earthquake with minor damages of structural elements

The following codes are used for analysis purpose;

1. Indian Standard Code

IS 1893(Part 1):2002 and IS13920:1993.

2. European code

EUROCODE 8: 1998

3. American code

ASCE 7-05

Linear Static analysis is applying load in linear pattern.

\section{MODELLING AND ANALYSIS}

A multi-storey building of $\mathrm{G}+10$ with $3 \times 3$ bays is considered for this study as shown in fig 1 . The base dimension of the plan is $9 \mathrm{~m} \times 9 \mathrm{~m}$. the typical storey height is $3 \mathrm{~m}$ for all storeys. The structural elements are considered as square for all storeys. The building is designed for all three codal provisions as mentioned above. A Linear Static analysis is done using ETABS 2015. The model is studied for all three code for severe zone with medium soil condition.

\subsection{PLAN AND ELEVATION OF THE BUILDING}

MODEL: Plan and Elevation of the building

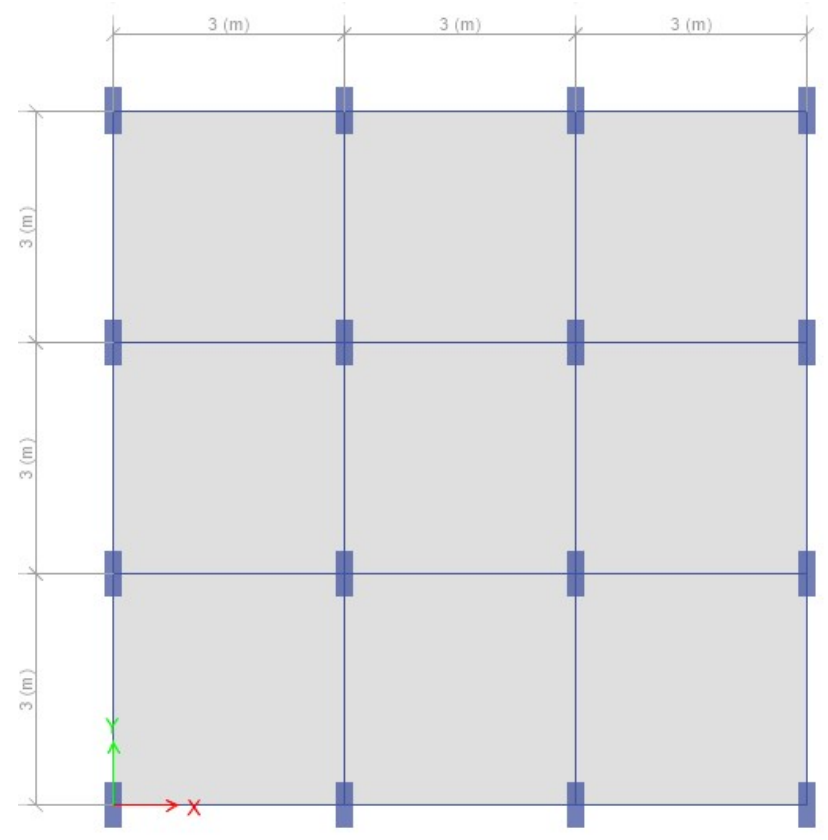

Fig (1). Plan of frame 


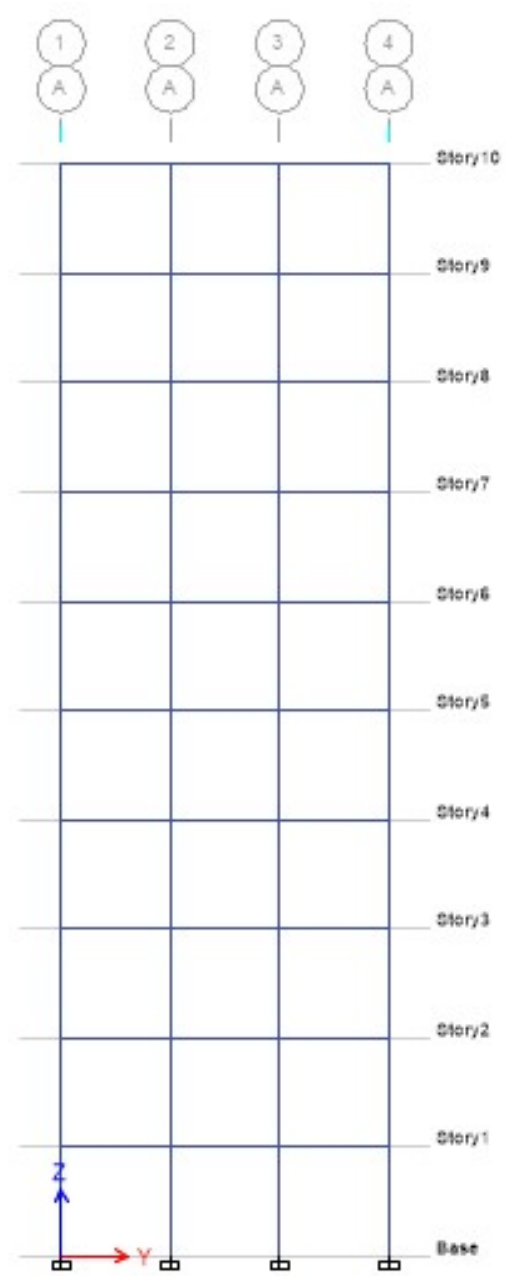

Fig (2). Elevation of frame

Table 1- Preliminary Data

\begin{tabular}{|l|l|}
\hline $\begin{array}{l}\text { DETAILS OF } \\
\text { BUILDING }\end{array}$ & FOR ALL STORIES \\
\hline Number of storey & $\mathrm{G}+10$ \\
\hline Storey Height & $3 \mathrm{~m}$ \\
\hline Beam size & $230 \mathrm{~m}^{*} 600 \mathrm{~m}$ \\
\hline Column size & $230 \mathrm{~m}^{*} 600 \mathrm{~m}$ \\
\hline Slab Thickness & $125 \mathrm{~m}$ \\
\hline Wall Thickness & $230 \mathrm{~mm}$ \\
\hline Grade of Concrete & $\mathrm{M} 25$ \\
\hline Grade of Steel & Fe415 \\
\hline
\end{tabular}

\subsection{METHODOLOGY OF THE PROJECT}

In this study, linear static analysis is done to find out the response of the building. The storey displacement, shear and drift is determined using ETABS software. The building is designed and detailed as per the codes and the results were compared and discussed.

\section{RESULTS AND DISCUSSIONS}

\subsection{RESULTS FOR EACH CASES}

Case(i). Analysis result obtained using IS Code

\section{DISPLACEMENT(mm)}

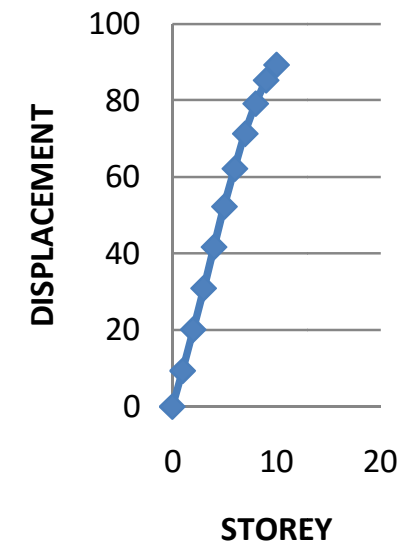

Fig (3)

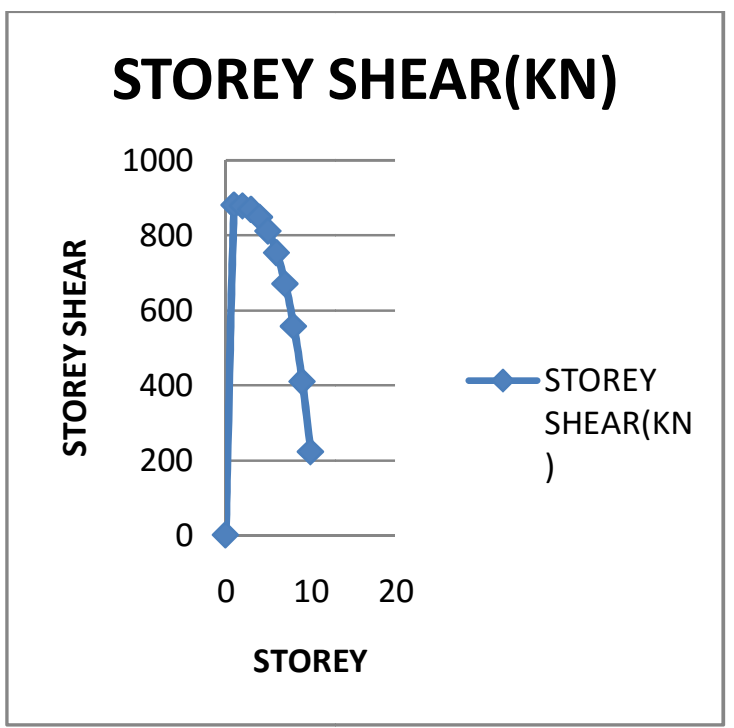

Fig (4)

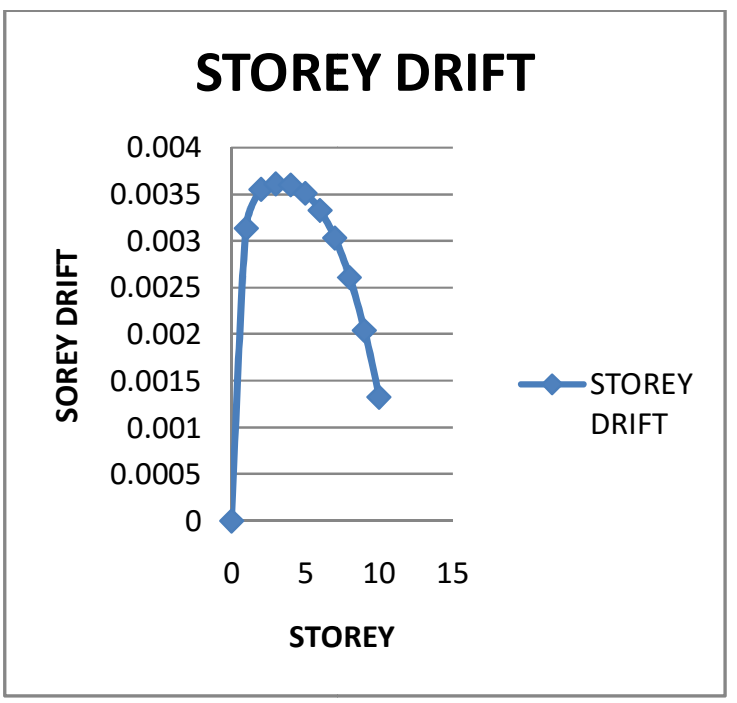

Fig (5)

Fig (3),(4),(5). Shows the displacement, shear and drift for the building 
Case (ii) Analysis Result obtained using EURO code

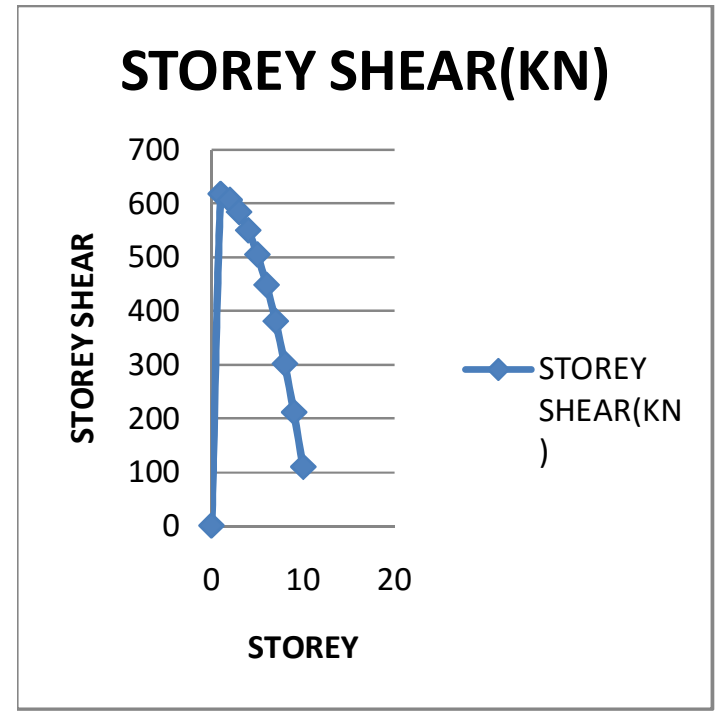

Fig (6)

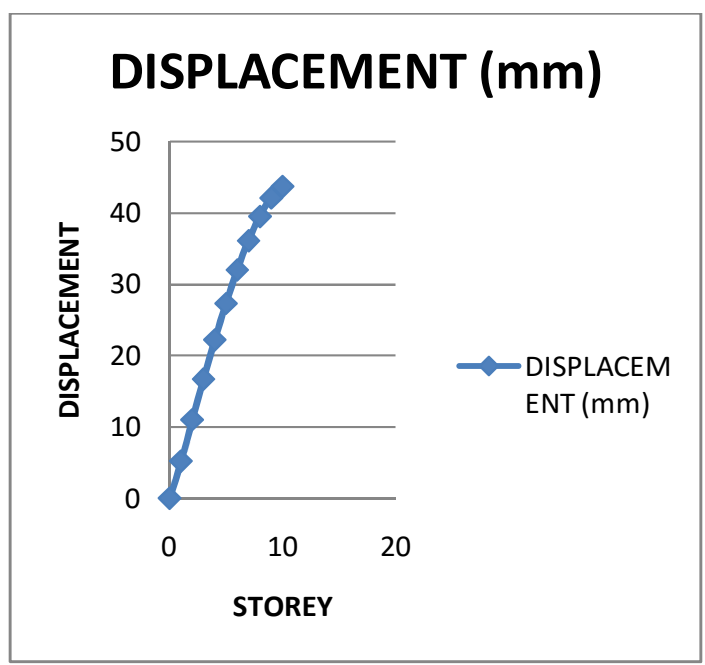

$\operatorname{Fig}(7)$

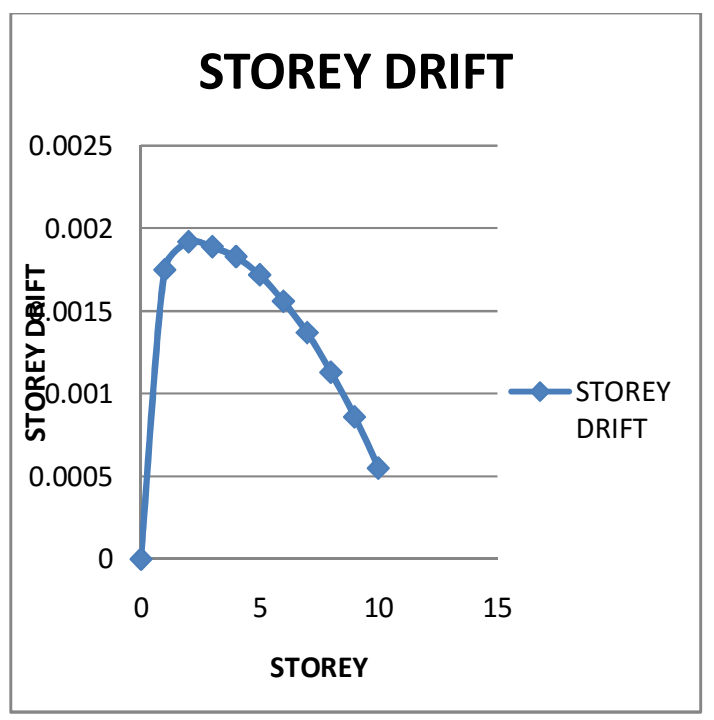

Fig (8)

Fig (6),(7)\&(8). Shows the shear,displacementand drift of the structure
Case (iii) Analysis Result obtained using ACI code

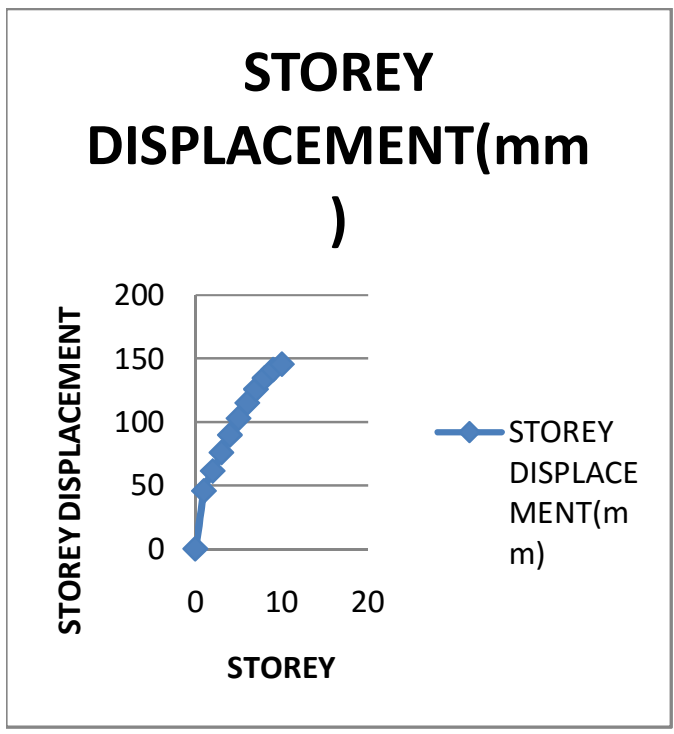

Fig (9)

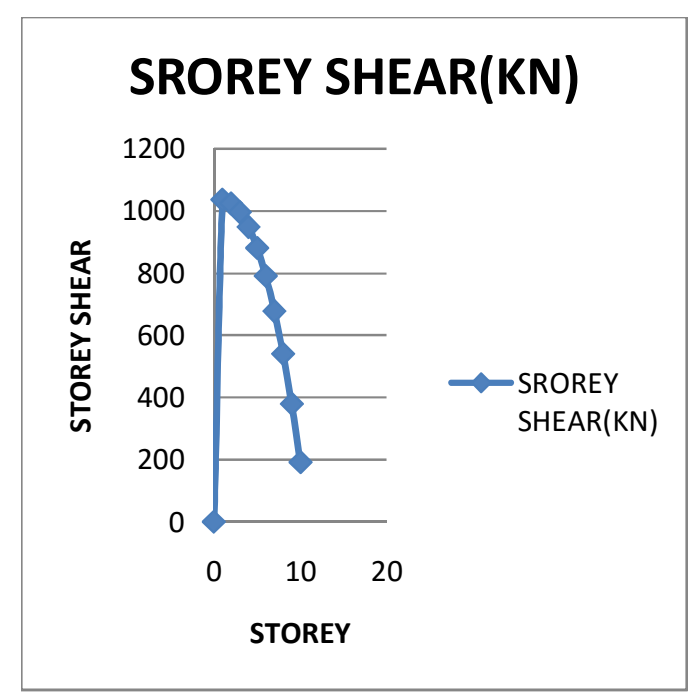

Fig (10)

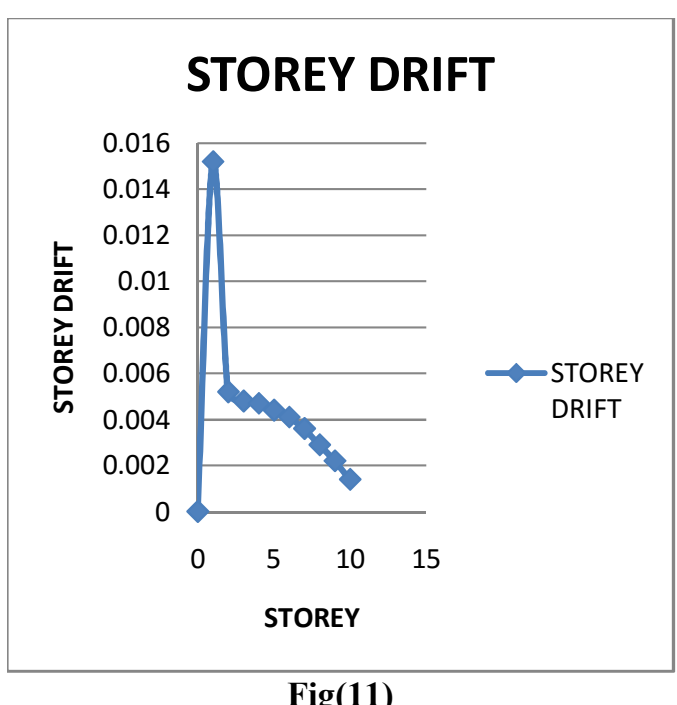

Fig (9),(10)\&(11) shows the displacement, shear and drift of the structure 


\subsection{COMPARATIVE ANALYSIS}

\subsubsection{STOREY DISPLACEMENT:}

Table 2. Comparison result of Displacement

\begin{tabular}{|r|r|r|r|}
\hline \multicolumn{1}{|c|}{ Storey } & \multicolumn{1}{|c|}{ IS CODE } & \multicolumn{1}{|c|}{ EURO CODE } & \multicolumn{1}{l|}{ ACI CODE } \\
\hline Base & 0 & 0 & 0 \\
\hline 1 & 9.4 & 5.2 & 45.7 \\
\hline 2 & 20.1 & 11 & 61.4 \\
\hline 3 & 30.9 & 16.7 & 75.9 \\
\hline 4 & 41.7 & 22.2 & 89.9 \\
\hline 5 & 52.3 & 27.3 & 103.1 \\
\hline 6 & 62.2 & 32 & 115.3 \\
\hline 7 & 71.3 & 36.1 & 126 \\
\hline 8 & 79.2 & 39.5 & 134.8 \\
\hline 9 & 85.3 & 42.1 & 141.5 \\
\hline 10 & 89.3 & 43.7 & 145.7 \\
\hline
\end{tabular}

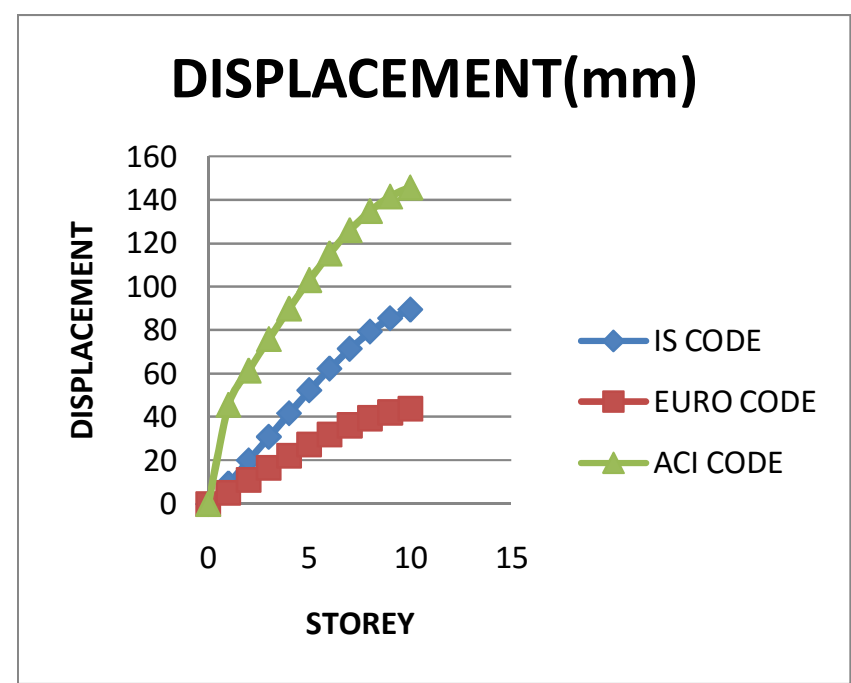

Fig 12. Comparison result of Displacement for all cases

\subsubsection{STOREY SHEAR:}

Table 3. Comparison result of Storey Shear

\begin{tabular}{|r|r|r|r|}
\hline Storey & \multicolumn{1}{|l|}{ IS CODE } & EURO CODE & ACI CODE \\
\hline Base & 0 & 0 & 0 \\
\hline 1 & 880.75 & 618.4 & 1037.6 \\
\hline 2 & 878.44 & 607.09 & 1025.56 \\
\hline 3 & 869.19 & 584.47 & 996.93 \\
\hline 4 & 848.39 & 550.54 & 949.39 \\
\hline 5 & 811.41 & 505.3 & 881.29 \\
\hline 6 & 753.63 & 448.76 & 791.28 \\
\hline 7 & 670.42 & 380.896 & 678.23 \\
\hline 8 & 557.17 & 301.73 & 541.15 \\
\hline 9 & 409.25 & 211.25 & 379.17 \\
\hline 10 & 222.03 & 109.46 & 191.49 \\
\hline
\end{tabular}

\section{STOREY SHEAR(mm)}

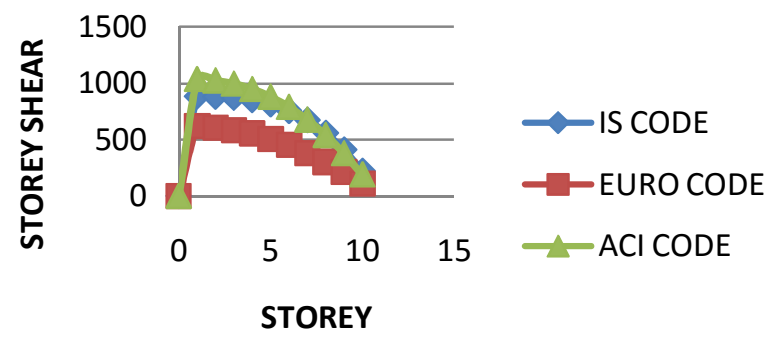

Fig 13. Comparison result of Storey shear for all cases

\subsubsection{STOREY DRIFT:}

Table 4. Comparison result of Storey Drift

\begin{tabular}{|r|r|r|r|}
\hline Storey & IS CODE & EURO CODE & ACI CODE \\
\hline Base & 0 & 0 & 0 \\
\hline 1 & 0.003136 & 0.00175 & 0.0152 \\
\hline 2 & 0.003555 & 0.00192 & 0.0052 \\
\hline 3 & 0.003612 & 0.00189 & 0.0048 \\
\hline 4 & 0.003602 & 0.00183 & 0.0047 \\
\hline 5 & 0.003513 & 0.00172 & 0.0044 \\
\hline 6 & 0.003329 & 0.00156 & 0.0041 \\
\hline 7 & 0.003033 & 0.00137 & 0.0036 \\
\hline 8 & 0.00261 & 0.00113 & 0.0029 \\
\hline 9 & 0.002043 & 0.00086 & 0.0022 \\
\hline 10 & 0.001327 & 0.00055 & 0.0014 \\
\hline
\end{tabular}

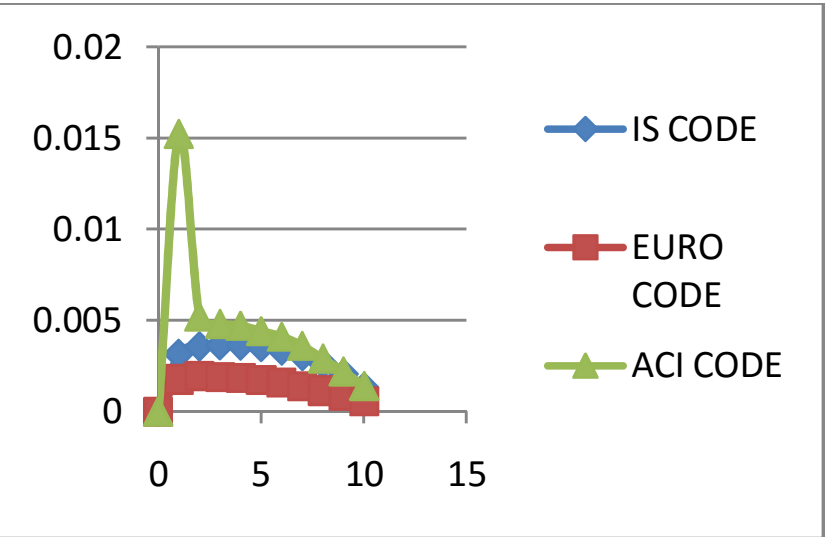

Fig 14. Comparison result of Storey Drift for all cases

\section{CONCLUSIONS}

- The analysis as per ACI code shows more displacement, storey shear and storey drift when compared with IS standard and Euro code.

- The displacement, shear and drift is maximum for first story for all cases.

- Comparing IS and EURO code, the displacement is increased by $50 \%$ for all stories as per IS code than EURO code. For Euro and ACI code, the displacement is varied from $88 \%$ to $70 \%$ from the base to top storey. 
- Comparing the storey shear for EURO and IS code, the value varies from $30 \%$ to $50 \%$ from base to top floor. For EURO and ACI codes, the shear varies from $40 \%$ to $43 \%$.

- Comparing the Storey Drift for EURO and IS code, the value varies from $44 \%$ to $59 \%$. For EURO and ACI codes, the drift varies from $88 \%$ to $60 \%$.

\section{REFERENCES}

[1] Jaya Prakash Kadali,M.K.M.V.Rathnam Static Analysis of Multistoreyed RC Buildings By Using Pushover Methodology International Journal for Innovative Research in Science \& Technology Volume1,Issue 8, January 2015 pp113-124.1989.

[2] Mr.K.Lova Raju, Dr.K.V.G.D.Balaji," Effective location of shear wall on performance of building frame subjected to earthquake load," International Advanced Research Journal in Science, Engineering and Technology Vol. 2, Issue 1, January 2015, pp 3336.

[3] Md. Rashedul Kabir, Debasish Sen, Md. Mashfiqul Islam I,"Response of multi-storey regular and irregular buildings of identical weight under static and dynamic loading in context of Bangladesh," International journal of Civil and Structural Engineering, Volume 5, No 3, February 2015, pp 252-260.

[4] Akshay V. Raut, Prof. RVRK Prasad, "Pushover Analysis of $\mathrm{G}+3$ Reinforced Concrete Building with soft storey," IOSR Journal of Mechanical and Civil Engineering , Volume 11, Issue 4 Ver. I (Jul-Aug. 2014), PP 25-29

[5] Lakshmi K.O, Prof. Jayasree Ramanujan, Mrs. Bindu Sunil, Dr. Laju Kottallil, Prof. Mercy Joseph Poweth,"Effect of shear wall location in buildings subjected to seismic loads," ISOI Journal of Engineering and Computer science, Volume 1 Issue 1;2014, Page No. 07-17,

[6] Nitin Choudhary, Prof. Mahendra Wadia, "Pushover Analysis of R.C. Frame Building with Shear Wall," IOSR Journal of Mechanical and Civil Engineering , volume 11, Issue 2 Ver. V (Mar-Apr. 2014), PP 09-13

[7] Riza Ainul Hakim, Mohammed Sohaib Alama, Samir A. Ashour, "Seismic Assessment of an RC Building Using Pushover Analysis," Engineering, Technology \& Applied Science Research Vol. 4, No. 3, 2014, pp:631635.

[8] Praveen Rathod ,Dr.S.S.Dyavanal, "Non-Linear Static Analysis of G+6 Storeyed RC Buildings with Openings in Infill Walls," Int. Journal of Engineering Research and Applications, Vol. 4, Issue 9( Version 5), September 2014, pp.51-58.

[9] A.Cinitha, P.K. Umesha, Nagesh R. Iyer, "Nonlinear Static Analysis to Assess Seismic Performance and Vulnerability of Code - Conforming RC Buildings," WSEAS TRANSACTIONS on APPLIED and THEORETICAL MECHANICS, Issue 1, Volume 7, January 2012,pp39-48.

[10] C. Bhatt, R. Bento, "A Comparison between American and European codes on the Non Linear Static Analysis of RC Buildings," $15^{\text {th }}$ World Conference on Earthquake Engineering, Lisbon 2012
[11] IS 1893 (Part 1): 2002 Indian Standard Criteria for Earthquake Resistant Design of Structures, Bureau of Indian Standards, New Delhi 110002.

[12] IS 456-1964, 1978, 2000 Indian Standard Code of Practice for Plain and Reinforced Concrete, Indian Standards Institution, New Delhi-110002

[13] Applied Technology Council, ATC-40,(1996), "Seismic Evaluation and Retrofit of Concrete Buildings", Vol.1 and 2, California.

[14] ACI Manual of Concrete Practice 2008,Part3,American Concrete Institute

[15] Eurocode 8-Design of structures for earthquake resistance-Part3: Assessment and retrofitting of buildings, BS EN 1998-3:2005.

[16] FEMA 440 , “ Improvement of Nonlinear Static Seismic Analysis Procedures", ATC 55 for the the Federal Emergency ManagementAgency, Washington, D.C, 2005.

[17] ASCE 7-05- Minimum Design loads for Building and other structures

[18]EUROCODE8- Design of structures for Earthquake Resistant 